\title{
Wyobrażenie Syberii i Mandżurii w prozie Igora Newerlego
}

\begin{abstract}
W artykule zaprezentowane zostały dwie powieści Igora Newerlego, których miejscami akcji są Syberia (Wzgórze Btękitnego Snu) oraz Mandżuria (Leśne Morze). Literackie obrazy obu krain stanowią próbę przezwyciężenia związanego z nimi imaginarium ugruntowanego $\mathrm{w}$ polskiej kulturze. W twórczości Newerlego wyraźna jest tendencja do eksponowania wartości dialogu z Innym w ramach autoidentyfikacji.
\end{abstract}

Stowa kluczowe: Igor Newerly, Sybir, Syberia, zesłanie, Mandżuria

Interesującą płaszczyznę badań nad problematyką dialogu międzykulturowego może stanowić literatura piękna. Autorzy nierzadko kreują obrazy innych zbiorowości oraz przestrzeni, w których owe zbiorowości żyją, odwołując się do utrwalonej we własnej kulturze wiedzy, nie zaś do osobistych doświadczeń. Tworzywem literackim w znacznym stopniu musi być $\mathrm{w}$ takim wypadku wyobraźnia. Artyści, którzy miejscem akcji swoich utworów czynią obszary inne niż rodzime, przyczyniają się do utwierdzania w danej kulturze pewnego zespołu wyobrażeń na temat obcych zbiorowości lub świadomie dążą do zakwestionowania ugruntowanych co do nich przekonań. Właściwa literaturze imagologia terytorialna poddawana jest refleksji badaczy jako geografia wyobrażona ${ }^{1}$.

\footnotetext{
${ }^{1}$ Termin rozpowszechnił się dzięki pracom Edwarda Saida, który w książce Orientalizm pisał, iż „kreacyjna geografia i historia pomagają umysłowi - poprzez udramatyzowanie odległości i różnicy pomiędzy tym, co jest mu bliskie, a tym, co odległe - wzmocnić jego poczucie siebie". E. Said, Orientalizm, przeł. M. Wyrwas-Wiśniewska, Poznań 2005, s. 95.
} 
Proza Igora Newerlego pozwala na prześledzenie, jakie wyobrażenia Syberii i Mandżurii powstawać mogą $\mathrm{w}$ twórczości pisarza polskiego $\mathrm{w}$ ramach próby literackiego ich przedstawienia. Choć obie krainy położone są poza Europą, to jednak silnie związane są z historią, kulturą, a zatem i tożsamością Polaków. Sprawa jest interesująca, zwłaszcza jeśli wziąć pod uwagę tożsamość samego autora. Igor Newerly urodził się w 1903 r. w Białowieży jako syn carskiego podporucznika Mikołaja Abramowa i Teresy Newerly, córki wielkiego łowczego Puszczy Białowieskiej - Czecha Józefa Newerlego. Chociaż młodość spędził głównie w Rosji, od czasu powrotu do Polski w 1924 żył, pracował i pisał - po polsku. Jest autorem kilku powieści i kilkunastu opowiadań.

\section{Przestrzenie tożsamości}

Interdyscyplinarność współczesnych koncepcji metodologicznych odzwierciedla sama ich nomenklatura, sygnalizująca usytuowanie perspektywy badawczej na przecięciu odległych, wydawałoby się, od siebie dziedzin nauki. Od co najmniej dwóch dekad dyskurs humanistyczny wzbogaca słownik o pojęcia charakterystyczne dla nauk ścisłych, wypróbowując na różne sposoby swój transgresywny potencjał (ostatnio dokonuje się np. zwrot cyfrowy ${ }^{2}$ ). Owe egzogenne elementy włączane są $\mathrm{w}$ poszczególne narracje, umożliwiając konstruowanie $\mathrm{w}$ procesach interpretacyjnych nowych, niewydobytych jeszcze znaczeń. Ogromny sukces odnoszą po tzw. zwrocie przestrzennym subdyscypliny humanistyki w swoich perspektywach anektujące koncepcje wypracowane na gruncie geografii: geopoetyka, geohistoria czy na przykład geofilozofia. Znaczenie tych rozpoznań teoretycznych podsumowuje między innymi Elżbieta Rybicka, podkreślając, iż:

Dowodzą one przede wszystkim odejścia od myślenia o przestrzeni jako kategorii abstrakcyjnej w stronę miejsca i konkretnych lokalizacji - w konsekwencji kultura i wiedza zawsze są już usytuowane przestrzennie, a zarazem postrzegane i badane z konkretnego (jakkolwiek nie zawsze stałego) punktu widzenia ${ }^{3}$.

Jeżeli kultura usytuowana jest przestrzennie, to tak samo można widzieć usytuowanie tożsamości zbiorowej, której istnienie właśnie wspólnota kulturowa gwarantuje. Należałoby zapytać, jakiego rodzaju przeobrażeniom ulega tożsamość podmiotowa oderwana od swojej „konkretnej lokalizacji”. Nie ulega wątpliwości, iż doświadczenie wykorzenienia zmusza podmiot do reidentyfikacji

\footnotetext{
${ }^{2}$ Zob. Zwrot cyfrowy w humanistyce, red. A. Radomski, R. Bomba, Lublin 2013.

${ }^{3}$ E. Rybicka, Geopoetyka, geokrytyka, geokulturologia. Analiza porównawcza pojęć, „Białostockie Studia Literaturoznawcze" 2010, nr 2, s. 27.
} 
(wszak „oderwanie” nie jest przypadkiem dobrowolnego przemieszczenia, na jakie decyduje się na przykład nomada, którego, jak podkreślał Kenneth White, praktyki translokacyjne wynikają z pragnienia wyjścia poza dotychczasowe Ja).

\section{Polacy na Wschodzie}

Oderwanie od miejsca, o którym mówi się „swoje”, może stanowić pewien rodzaj sytuacji granicznej w sensie, jaki nadaje jej Karl Jaspers, jest jednak przede wszystkim sytuacją trans-graniczną, czyli taką, która zmusza do zmagań z doświadczeniem obcości i wymaga wypracowania z nową przestrzenią relacji, pozwalającej tę obcość przezwyciężyć. Asymilacja może polegać na weryfikacji wyobrażeń, które dotąd organizowały myślenie o specyfice zjawisk społecznych właściwych danej kulturze. Przekroczenie linii demarkacyjnej, wyznaczającej granice tego, co „swoje”, uruchamia jednocześnie proces porządkowania obrazów i wspomnień dotyczących miejsca pochodzenia, a zatem organizacji przestrzeni uwewnętrznionej na migotliwej tkance pamięci.

Nowe centrum oznacza konieczność dookreślenia, w jaki sposób oswajać doświadczenie przeszłości z projektem przyszłości. W geokrytyce Bertranda Westphala nazywa się to mianem multifokalizacji, czyli zdefiniowania relacji podmiotu z przestrzenią, co wynika przede wszystkim uwarunkowania dystansu, który dotąd generował poczucie kulturowej odrębności.

Ciekawym przedmiotem refleksji dla zorientowanych geograficznie metodologii są z pewnością wszelkiego rodzaju literackie reprezentacje Syberii, która dla polskiego czytelnika częściej jest Sybirem, czyli „ziemią przeklętą”, „lodowym piekłem”, „krainą, gdzie nie ma nadziei”, „krainą wiecznych śniegów i wiecznej tęsknoty"4. Kraina ta przez niemalże trzysta lat kojarzyła się jednoznacznie z miejscem zesłania i kaźni, ale po odzyskaniu niepodległości Polacy zaczęli podejmować próby zmiany tej optyki. Zainicjowane zostały pełne rozmachu i entuzjazmu projekty kolonizacyjne, dyskutowane m.in. w wydawanym do 1939 r. czasopiśmie „Sybirak”. Eksponowano doniosłość zasług Polaków, którzy na wygnaniu prowadzili misję cywilizacyjną wśród pozostałych mieszkańców tajgi, zachowując wyraźną odrębność kulturową ${ }^{5}$. Można wnioskować, że wraz z nimi zesłano na Syberię cząstkę Europy.

\footnotetext{
${ }^{4}$ Por. Z. Trojanowiczowa, Sybir Romantyków, Kraków 1992.

${ }^{5}$ Wpisuje się to doskonale w mityczną opozycję Wschód - Zachód. Pisał o tym m.in. Božidar Jezernik: „Europejczycy przez wieki odróżniali członków „społeczeństw cywilizowanych” od „prymitywów”, „barbarzyńców” i „dzikusów” tylko po to, by móc uznać samych siebie za ucywilizowanych. Po to właśnie potrzebowali swojego przeciwieństwa, Innego". B. Jezernik, Dzika Europa. Bałkany w oczach zachodnich podróżników, przeł. P. Oczko, Kraków 2007, s. 20.
} 
Począwszy od końca XIX wieku zaczęła rozrastać się kolonia polska w Harbinie, na terenie dzisiejszych Chin. Szacuje się, iż w tym mandżurskim mieście w krótkim czasie zamieszkało ponad siedem tysięcy Polaków, głównie zatrudnionych przy budowaniu Kolei Wschodnio-Chińskiej. Najbardziej znaczące wpływy - rosyjskie - pozwoliły w heterogenicznym kulturowo Harbinie widzieć „orientalny Petersburg”, czyli najbardziej ,zachodnie” miasto na wschodzie. W Mandżurii Polacy, skupieni wokół Gospody Polskiej, także prowadzili znaczącą działalność kulturalną, czego dowodzi Kim Yong-Deog w szkicu Życie kulturalne Polaków w Mandżurii w latach 1897-1947.

Zarówno Syberia, jak i Mandżuria, stały się miejscem akcji dwóch powieści Igora Newerlego: Wzgórza Błękitnego Snu ${ }^{7}$ i Leśnego Morza ${ }^{8}$.

\section{Syberia Newerlego}

Główny bohater pierwszej powieści, opublikowanej tuż przed śmiercią Newerlego, w 1987 roku, to zesłaniec z 1910 niesłusznie oskarżony o zamach na premiera carskiego Stołypina - Bronisław Najdarowski. Po czterech latach katorgi skazany na wieczne osiedlenie rozpoczyna nowe życie w Starych Czumach, położonych w pobliżu Nerczyńska. Narracja - choć nie pozbawiona realistycznych opisów trudnych warunków życia w tajdze - we fragmentach poświęconych charakterystyce syberyjskiej fauny i flory wydała się krytykom nazbyt sielankowa, wszak czy „krainę wiecznych śniegów i wiecznej tęsknoty" można opisywać w ten sposób:

W listopadzie ustaliła się zima na dobre. Sypnął śnieg i mróz ściął ziemię. Wypełnił zapadliny i doły, przykrył upadłe drzewa, krzaki, wszelki susz i zgniliznę, zrobiło się jaśniej, równo i przestronnie, a okiść na drzewach miała kształt obły i dostojny. Suchość powietrza i brak wiatru łagodziły klimat, sorokowiki jeszcze nie nadeszły, toteż była to pora najprzyjemniejsza i najzdrowsza na Syberii ${ }^{9}$.

Tajga przedstawiona we Wzgórzu Btękitnego Snu fascynuje, hartuje, tchnie czymś, co identyfikować można jako ledwo słyszalne echa poprzedniego świata ${ }^{10}$.

Cyt. za T. Ewertowski, Doświadczanie przestrzeni jako konstruowanie kulturowego obrazu. Przykład Batkanów i Syberii, „Interlinie” 2011, nr 1, s. 94.

${ }^{6}$ Por. K. Yong-Deog, Życie kulturalne Polaków w Mandżurii w latach 1897-1947, „Postscriptum Polonistyczne" 2010, nr 2.

${ }^{7}$ I. Newerly, Wzgórze Błękitnego Snu, Warszawa 1987.

${ }^{8}$ Tenże, Leśne Morze, Warszawa 2009. Po raz pierwszy książka została opublikowana w 1960 r.

${ }^{9}$ I. Newerly, Wzgórze Btękitnego Snu, s. 126.

${ }^{10}$ Newerly, który jako dziecko wychowywał się w domu rodzinnym w sercu Puszczy Białowieskiej, a przez całe życie uciekał na łono natury podczas regularnych wypraw kajakowych, musiał ze szczególnym sentymentem myśleć o dzikiej przyrodzie tajgi. W jednym z autobiograficznych opowiadań ze zbioru Za Opiwarda, za siódma rzeka..., zatytułowanym Jak dobrze być czasem 
Równie podejrzanie wyglądać mogą serdeczne stosunki, jakie Najdarowski nawiązał z pozostałymi mieszkańcami regionu. Jak odnotował Adrian Uljasz:

Autor zaprezentował we Wzgórzu Blękitnego Snu część wyznawanego przez siebie systemu wartości sprowadzającą się do tolerancji etnicznej i religijnej. Propaguje tolerancję wobec Rosjan, autochtonicznych ludów Syberii, Żydów i chrześcijan wyznania prawosławnego. Tolerancji w stosunku do Rosjan uczy polskich czytelników relacja z dziejów przyjaźni między Bronisławem a Mikołajem Sawieliczem. Newerly ukazuje śmierć Czutkicha zabitego w tajdze przez bandytów i rozpacz Najdarowskiego po stracie przyjaciela. Wątek polsko-rosyjski stanowi także historia znajomości, a następnie miłości i początków małżeństwa Bronisława Najdarowskiego z zesłaną na Syberię Rosjanką, Wierą Lwowną Izwolską. Ekumenizm katolicko-prawosławny cechuje scenę, w której Newerly opisuje wigilię zachodniochrześcijańskich świąt Bożego Narodzenia przygotowaną dla Bronisława przez prawosławną Wierę [...], [która po ślubie] zmieniła wyznanie na rzymskokatolickie ${ }^{11}$.

Sympatia i życzliwa koegzystencja dwóch kultur, polskiej i rosyjskiej, nie jest jednak li tylko utopijną wizją Newerlego-pedagoga, jeśli nawet katorżników w syberyjskich miastach łączyły z Rosjanami przyjazne z reguły stosunki. Pisze o tym Wiktoria Śliwowska:

[...] warunki odbywania kary okazywały się często już nie tak przerażające. Nawet na katordze - samo słowo budziło wszak przerażenie - polscy zesłańcy nie byli długo zatrudniani, o czym zapewniają wszyscy pamiętnikarze. [...] Z reguły wykształceni, znający języki obce polscy katorżnicy i osiedleńcy byli dobrze widziani w domach miejscowych dygnitarzy i zamożnych kupców w charakterze nauczycieli języków, rysunków, muzyki, tańców; kierowali orkiestrami, dawali koncerty itd. [...] Podobnie mimo zakazów lekarze zajmowali się praktyką medyczną, o ich umiejętnościach krążyły legendy, naczelnicy zaś, zobowiązani do przestrzegania wydawanych z centrum poleceń, sami, a zwłaszcza ich żony, woleli zasięgnąć porady u podległego im doktora katorżnika $\mathrm{z}$ wyższym wykształceniem niźli u miejscowego felczera. Patrzyli też „przez palce” na rozwijaną przez przestępców politycznych działalność gospodarczą. [...] Michał Gruszecki [...] pro-

waregiem, pisał o podążaniu śladami warega z czasów plemion słowiańskich: „Płynąłem za nim w odstępie wielu wieków przez dzikie poleskie rozlewisko, gdzie można cały dzień wiosłować i nie spotkać człowieka. Jak przed wiekami, leniwie płynął nurt i czas. Powietrze od skraju do skraju nieba pulsowało graniem bąków i derkaczy w szuwarach, komary, meszka, gzy cięły; siwe mgły poranne i wieczorne snuły się nad wodą i w ich kłębach zwidy rzeczy niepojętych, baśniowych, tajonych w jasny dzień". I. Newerly, Jak dobrze być czasem waregiem, [w:] Za Opiwarda, za siódma rzeka..., Warszawa 1985, s. 10.

${ }^{11}$ A. Uljasz, Syberia i Daleki Wschód w twórczości Igora Newerlego. Pisarska wizja, oceny, dyskusje, „Tematy i Konteksty” 2012, nr 2, s. 339. 
wadził świetnie prosperujący folwark, także korzystając z pracy licznych zesłańców chłopów; pożyczał też pieniądze na procent $\mathrm{i}$ - jak mawiano - cała okolica siedziała u niego w kieszeni. I nie były to fakty odosobnione ${ }^{12}$.

Wprawdzie nie ma tu mowy o katolicko-prawosławnych małżeństwach, ale Newerly wiedział najlepiej, że musi istnieć prawdopodobieństwo takich zaślubin, skoro podobny wątek miłosny pojawił się... w historii rodzinnej pisarza.

Bohater Wzgórza Btękitnego Snu nie jest już katorżnikiem, a jednym z niewielu mieszkańców Starych Czumów, do tego pracowitym i zdolnym. Życie w niewielkiej miejscowości, otoczonej zewsząd kilometrami lasów, jest na tyle trudne, że integracja i fuzja horyzontów kulturowych jest tyleż nieunikniona, co po prostu korzystna. Położone z dala od większych miast Stare Czumy to przestrzeń, w której upływ czasu wyznacza fizyczna praca i kalendarz myśliwski; z rzadka dociera tu wielka, rządząca losami narodów, Historia.

Izolacja, skupienie na codziennej pracy i wzajemne zaufanie pozwalają na przezwyciężenie różnic i obcości, dają podstawę do autoidentyfikacji w ramach tej małej wspólnoty. Symbolem ostatecznego zbratania jest budowa domu, pod dachem którego zamieszkają przedstawiciele narodu polskiego, rosyjskiego i żydowskiego, oraz Buriaci, których wdzięczność za pomoc w obliczu nieuchronnej śmierci głodowej także w końcu przeradza się w prawdziwe przywiązanie, co przypieczętowuje nadanie przestrzeni, w której stanął dom, buriackiej nazwy: Wzgórze Błękitnego Snu. Kiedy po 1918 roku Najdarowscy wracają do Polski, okazuje się, że przywiązanie do porzuconego życia nie pozwala im zakorzenić się w Warszawie: pozostaje im zapraszać ludzi „z grona sybiraków” i wspominać dom:

W starszym wieku, gorzej lub lepiej urządzeni w Polsce, nie mogli się jakoś zasymilować w odzyskanej ojczyźnie i wstydliwie tęsknili za Syberią. Lubili ludzi tamtejszych, surowych i gościnnych, dania i pieśni syberyjskie [...], gadali za północ z wypiekami na twarzy, z roziskrzonymi oczami, jak gdyby śnili swój błękitny sen ${ }^{13}$.

\section{Mandżuria Newerlego}

Wydana w 1960 roku powieść Leśne Morze dotyczy w dużej mierze życia polonii w Harbinie z czasów II wojny światowej. Wyróżnia ją też nasycenie niespotykanie dokładnymi, a przy tym emocjonującymi opisami szu-hai, czyli tytułowego Leśnego Morza, tajgi mandżurskiej. Główny bohater, Wiktor

\footnotetext{
${ }^{12}$ W. Śliwowska, Ucieczki z Sybiru, Warszawa 2005, s. 13-14.

${ }^{13}$ I. Newerly, Wzgórze Btękitnego Snu, s. 494.
} 
Domaniewski, to syn zesłańca, który wraz z żoną osiedlił się w głuszy Mandżurskich lasów, czekając na dzień, w którym powrót do Polski okaże się możliwy. Polskość, chrześcijańskie wartości i tradycje patriotyczne pielęgnowali w nim nie tylko rodzice, ale $\mathrm{i}$ nauczyciel historii $\mathrm{z}$ harbińskiego gimnazjum im. Henryka Sienkiewicza. Profesor Lech Koropko to w opinii Wiktora „romantyk niemożliwy, sarmacki w każdym calu", którego niepozornie wątła postura odznaczała się „wąsami Sobieskiego, Sobieskiego w latach najlepszej formy - prosto spod

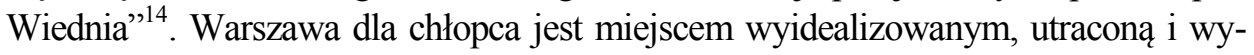
tęsknioną ojczyzną. Ten rodzaj doświadczenia tęsknoty jest chyba pewnym wariantem działania postpamięci, polegającym na dziedziczeniu przeżyć rodziców, co stanowi szczególny wynik procesów interioryzacyjnych. Zastanawiające jest jego przekonanie o tym, że:

Polacy nie są podobni do Europejczyków [...]. Zbyt wiele przeszli prześladowań, żeby jeszcze dokuczać komukolwiek. Polska jest krajem prawdziwej tolerancji i wszyscy tam, Ukraińcy, Żydzi, Białorusini czy Niemcy, żyją jak dzieci jednej matki ${ }^{15}$.

O ile naiwna wiara w możliwość utopii usprawiedliwiona jest zaufaniem do rodzicielskiej narracji, wydobywającej z siatki pamięci najpiękniejsze niteczki, to gest odróżnienia Polaków od Europejczyków jest dosyć zdumiewający. Wygląda na to, że dla Wiktora Polska pełni funkcję mitu, co dowodzi mitotwórczej aktywności pamięci, która na przestrzeni lat przekształca autentyczne doświadczenie w literaturę.

Wiktor przeżywa traumę, kiedy ze świadectwem maturalnym wraca po długiej rozłące do domu i zastaje pogorzelisko, a wkrótce okazuje się, że odpowiedzialni za podpalenie Japończycy skazali oboje jego rodziców na śmierć, dowiedziawszy się, że utrzymują kontakt $\mathrm{z}$ rewolucjonistą Bagornym. Jest to inny wariant gwałtownego przeformułowania relacji podmiot-przestrzeń, gdyż w tym przypadku podmiot pozostaje związany z dramatyczną pustką, namacalne ślady po stojącym tu dopiero co budynku tylko intensyfikują doznanie braku, ponieważ to, co semantyzowało przestrzeń, wszystko, co nadawało jej konstytutywne znaczenia, uległo zniszczeniu.

Próba zagospodarowania wyrwy, podobnie jak w przypadku bohatera Wzgórza Błękitnego Snu, wymaga od Wiktora ciężkiej pracy i zaufanych ludzi, ponieważ grozi mu niebezpieczeństwo i musi się ukrywać. Dom powstaje dzięki wspólnocie komunizującej grupy przyjaciół. Oprócz Polaków, Wiktor obdarza

\footnotetext{
${ }^{14}$ Tenże, Leśne Morze, s. 167.

${ }^{15}$ Tamże, s. 357.
} 
zaufaniem Rosjan, przy czym z reguły są to ludzie dobrze doń usposobieni. Spotkana przypadkowo para ukrywających się, zbiegłych z sowieckiego łagru rewolucjonistów bezinteresownie pomaga Domaniewskiemu przetrwać po uniknięciu śmierci, jednak tęskniący za obaloną epoką i niedoszłą karierą naukową Ałsufjew „Z wielkopańskim gestem”, inteligent o naturze pyszałka, budzi w Wiktorze pokłady zdecydowanej niechęci, skrywanej raczej przez litość. Rewolucjonista Bagorny, początkowo bohater, z czasem okazuje się tak oddany swojej misji, że gubi ideały człowieczeństwa, co jest dla Domaniewskiego jednoznaczne z moralną klęską.

Młody Polak ceni najwyżej cnoty powściągliwych, wyważonych i mądrych Chińczyków, potrafiących przyjaźnić się ze zwierzętami i doskonale znających tajgę. Jedynym bohaterem negatywnym spośród Chińczyków jest sprzedajny $\mathrm{Wu}$, odpowiedzialny za tragedię, która spotkała rodzinę Domaniewskich. Wspólnym wrogiem są przedstawiciele kultury japońskiej, cechujący się wyrafinowanym okrucieństwem. Nie udało się Domaniewskiemu spotkać ani jednego porządnego Japończyka. On sam jednak jest, podobnie jak Najdarowski, uosobieniem męskości jako doskonały myśliwy. Z łatwością zyskuje względy kobiet, które są mu tak oddane, że gotowe by były żyć w haremie. Miłość, która łączy go z Chinką Aszyche, stanowiła dla krytyków motyw o delikatnie dydaktyzującym wydźwięku, zwłaszcza, że ideały humanizmu i tolerancji umacniał w sobie Newerly pod okiem samego Janusza Korczaka.

W przypadku komuny mandżurskiej uwikłanie w kontekst historyczny jest nie do przezwyciężenia. Nie udaje się stworzyć wspólnoty tak zgodnej jak na Syberii, gdyż Historia dzieje się zbyt blisko, wkracza w przestrzeń Leśnego Morza i domaga się od jego mieszkańców działania.

\section{Zakończenie}

Wymowa powieści Leśne Morze to pesymistyczna wizja upadku cywilizacji, do którego prędzej czy później doprowadzą konflikty międzynarodowe, gdyż każdy, kto śni piękne sny o imperium, lud swój skazuje na koszmary. W Mandżurskiej tajdze, tak jak na Syberii pokazanej we Wzgórzu Błękitnego Snu, żyją zwierzęta mądrzejsze od ludzi, znające swoje miejsce, posłuszne prawom przyrody. Światem ludzi targają namiętności, a te produkują systemy ideologiczne, wraz z nimi zaś obietnicę postępu. Jednostka została zepchnięta na margines, $w$ centrum jest masa, wartość ma tłum, który jest w stanie popchnąć tryby w mechanizmach historycznych. Jednak to nie afirmatywne walczące oświecenie, a spokojne proste życie u boku drugiego człowieka może mieć moc ocalającą człowieczeństwo. Poza takim życiem jesteśmy bezdomni. 


\section{Bibliografia}

Ewertowski T., Doświadczanie przestrzeni jako konstruowanie kulturowego obrazu. Przykład Bałkanów i Syberii, „Interlinie” 2011, nr 1, s. 91-98.

Jezernik B., Dzika Europa. Bałkany w oczach zachodnich podróżników, przeł. P. Oczko, Kraków 2007.

Newerly I., Jak dobrze być czasem waregiem, [w:] Za Opiwarda, za siódma rzeka..., Warszawa 1985.

Newerly I., Leśne Morze, Warszawa 2009.

Newerly I., Wzgórze Btękitnego Snu, Warszawa 1987.

Rybicka E., Geopoetyka, geokrytyka, geokulturologia. Analiza porównawcza pojęć, „Białostockie Studia Literaturoznawcze" 2010, nr 2, s. 27-39.

Said E., Orientalizm, przeł. M. Wyrwas-Wiśniewska, Poznań 2005.

Śliwowska W., Ucieczki z Sybiru, Warszawa 2005.

Trojanowiczowa Z., Sybir Romantyków, Kraków 1992.

Uljasz A., Syberia i Daleki Wschód w twórczości Igora Newerlego. Pisarska wizja, oceny, dyskusje, „Tematy i Konteksty” 2012, nr 2, s. 325-342.

Yong-Deog K., Życie kulturalne Polaków w Mandżurii w latach 1897-1947, „Postscriptum Polonistyczne" 2010, nr 2, s. 117-142.

Zwrot cyfrowy w humanistyce, red. A. Radomski, R. Bomba, Lublin 2013.

\section{The image of Siberia and Manchuria in the works of Igor Newerly}

This article presents two novels of Igor Newerly, where action is set in Sibiria (Wzgórze Btękitnego Snu) and Manchuria (Leśne Morze). Literary portrayals of both regions attempt to overcome the ingrained in Polish culture visions of depicted lands. In Newerly's literary work there is a clear trend to emphasise the importance of dialogue with the Other in self-identification process.

Keywords: Igor Newerly, Sibir, Siberia, exile, Manchuria 